\title{
ENERGY PARAMETERS OF KAZAKHSTAN-AMERICAN RELATIONS: GEOPOLITICAL AND INTERNATIONALLY LEGAL ASPECTS
}

Bekbolat Bakbergenovich Almadiyev ${ }^{1}$

\begin{abstract}
The strategic partnership of the Republic of Kazakhstan with the US of America contains a key vector in the form of the American Kazakhstan's energetic diplomacy and external policy. This is due to geopolitical, geo-economic, geo-strategic, resource and energy, and military policies. Because of the experience gained from the partnership, this bilateral relationship continues to demonstrate progressive development and contributes towards expanding cooperation with other countries of North, Central, and Latin America. This is important in the context of the dynamic development of the fuel and energy complex of Kazakhstan country, and export of Kazakhstan`s energy resources through regional and global markets.
\end{abstract}

JEL Classification Number: P0, P2, DOI: http://dx.doi.org/10.12955/cbup.v3.627

UDC Classification: 32

Keywords: Kazakhstan-American relationships, external policy, energetic diplomacy, priorities, and perspectives of the energetic cooperation

\section{Introduction}

\section{Energy measurements of foreign policy of the Republic of Kazakhstan}

The Decree of the President of the Republic of Kazakhstan on January 21, 2014 approved the Foreign Policy Concept of the Republic of Kazakhstan for 2014-2020 (Ministry of Foreign Affairs of the Republic of Kazakhstan [MFA of the RoK], 2014). This was in accordance with the President's message "Strategy Kazakhstan-2050: a new policy of the developed state", which represents the system of fundamental views on the principles and approaches, goals, priorities, and objectives of the foreign policy of the Republic of Kazakhstan (Nazarbayev, 2012).

This Foreign Policy Concept of the Republic of Kazakhstan (the Concept) focuses on traditional issues, such as national security and sovereignty of the country, as well as promoting economic cooperation and attracting investment and technology. It also determines the energy and environmental dimension of Kazakhstan's foreign policy as an important priority, and includes:

- stage wise transition to a "green economy", including the EXPO-2017 "Energy of the Future";

- strengthening regional and global energy security, to achieve a balance of interests of producing countries, transit countries and consumer countries of energy resources, the creation of a diversified, stable and secure export routes;

- implementation of economic and resource and export potential, its extension on new and traditional world markets;

- determination of the legal status of the Caspian Sea, and stability and friendly relations among the littoral states based on accepted principles and norms of international law;

- expansion of international cooperation for the diversification and technological modernization, diversification, and increase marketability of the national economy;

- the implementation of the "Green Bridge" Astana initiative, aimed at supporting the partnership between the public and private sectors in Europe, Asia, and the Pacific, and NGOs and international organizations in the implementation of programs and plans for "green growth";

\footnotetext{
${ }^{1}$ Bekbolat Bakbergenovich Almadiyev, Inspector General, Prime Minister's Department of the Republic of Kazakhstan; PhD student, the Academy of Public Administration, Under the President of the Republic of Kazakhstan, almadiev_bb@mail.ru
} 
- promotion of initiatives for the development and implementation of advanced services in the field of sustainable energy, including global energy and environmental strategy, aimed at finding solutions to the problems of post-industrial society; and

- cooperation with international organizations and donors for the rehabilitation of the former Semipalatinsk nuclear test site and participate in the achievement of a world without nuclear weapons.

Among the country and regional priorities, the Concept (MFA of the RoK, 2014) notes that the Republic of Kazakhstan is:

- "continuing to strengthen the strategic partnership with the US, aimed at the development of political, trade-economic, investment, energy, scientific-technical and humanitarian cooperation, addressing topical issues on the international agenda"; and

- "paying a great importance to cooperation with the countries of North, Central and Latin America. The priority in this work is given to the development of trade-economic, investment and cultural ties, promote common interests within the framework of the UN and other international organizations."

The strategic partnership of Kazakhstan with the US was, and remains, a key vector in the American Kazakh energy diplomacy and foreign policy. This is due to geo-political, geo-economic, geo-strategic, resource and energy, and military policies, which are based on the status of these countries, with the United States (US) a world power, and Kazakhstan a regional power in Central Asia.

Indeed, the bilateral relations are much broader than solely relating to energy cooperation. For example, in Kazakhstan there are about 300 joint ventures, with the US one of the largest investors. Since 1993, the US has invested more than USD 25 billion into Kazakhstan's economy. In 2013, the trade turnover between Kazakhstan and the US totaled USD 2.75 billion, 9\% more than in 2012.

The political leader of the US, President Barack Obama shows interest in maintaining the strategic nature of bilateral relations with the Republic of Kazakhstan, and therefore adheres to a balanced approach. This results from US recognition of the political development in Kazakhstan, the high dynamics of economic growth, improvements in the investment attractiveness of the market, and the effectiveness of measures to improve economic legislation.

In general, issues related to the security and development of the Caspian resources still prevail over all other issues, and are the strategic priority in the relations between Kazakhstan and the US. In this regard, an important area of bilateral cooperation, today, is the deepening of cooperation in the field of energy and security (Sultanov, 2012).

Strategic documents outline the main provisions of the US energy strategy, and these are the "Law on energy independence and security" issued in 2007, as well as the "Law on energy policy" issued in 2005 (The US Energy Independence and Security Act, 2007; MFA of the RoK, n.d. a).

In addition to the traditional relations with the US, the Concept also highlights plans for cooperation with other countries of the American continent.

In a notable interview, the Republic of Kazakhstan Minister of Foreign Affairs, Erlan Idrissov (2014a) stated:

At the end of last year, speaking in Astana at the Academy of Public Administration with a lecture, I said that the diplomacy of Kazakhstan "built up muscles" and now we intend to expand the geography of our representation abroad, and actively promote the public interest in the far corners of the world from Kazakhstan and offer Kazakhstan's experience of the world community for assistance in solving global and regional problems.. 
A few days earlier, Mr. Idrissov (2014b) acknowledged:

Today's realities require Kazakhstan to find new partners outside our traditional areas of interest. Last year, the Ministry of Foreign Affairs launched a large-scale work on the expansion of geography of partners of Kazakhstan in the new regions of the world for us."

In this regard, the maturing American countries are very important. Such countries as Mexico, Argentina and Brazil are included in the 20 largest economies in the world and become important players in the new multipolar world. Chile Colombia, Uruguay and other fast-growing economies of the continent are getting close to them. Among this region there are our traditional friends and partners, such as Cuba. The first step in the development of these partnerships, we currently have defined facilitating travel for our citizens and the establishment of trade and economic relations with these countries.

We are moving systematically worked out in accordance with the algorithm. Over the past year eased or completely abolish the visa regime with six Latin American countries: Brazil, Argentina, Chile, Ecuador, Colombia and Mexico, with which we have recently signed the first document in that direction.

The same work is being done with the developed countries of the American continent. A year as citizens of Kazakhstan gave 5-year-old US visa. The work on this agreement was initiated as far back as when I was Ambassador in Washington. The high level of confidence that we were able to build with our partners in the US, allows us to achieve a deeper level of liberalization of the visa regime and we eventually succeeded.

Mr. Idrissov (2014a) then assured:

We will develop and strengthen the cooperation with the countries of Latin America and the Caribbean, having great economic potential, which we can serve as a kind of bridgehead on the Eurasian continent, taking into account the integration processes in this space. As it was planned, in Mexico we opened our Embassy and signed an important agreement on visa-free travel for official delegations, which is the first step towards the full establishment of a visa-free regime for citizens of both countries. Thus, we have laid a solid foundation for cooperation with one of the fastest growing countries in the world, which, according to experts, will be able to enter the top ten economies in the world by 2050 .

In an online statement, the Ministry for Foreign Affairs of the Republic of Kazakhstan (n.d. a) declares:

The Kazakh diplomacy is intending to continue to "conquer" the countries of Latin America and the Caribbean. We have established diplomatic relations with thirty-one of the thirty-three countries in the region. Successfully operating our embassy in Brazil, the embassy in Mexico which was recently opened is activated. It is pleasant to note that in recent years, our relationship with Venezuela is dynamically developing. In 2012, Venezuela has opened a diplomatic mission in Kazakhstan. Resulting from meeting with Delsi Rodriguez we have signed a memorandum on political consultations, which are important in determining the long-term and mutually beneficial areas of cooperation.

The cooperation between Kazakhstan and the countries as described above are noted in a series of government online documents (Ministry for Foreign Affairs of the Republic of Kazakhstan, n.d. b-g).

\section{Diplomatic instruments of Kazakhstan -American energy cooperation}

Energy is one of the most important elements of the Kazakh-American cooperation. Every year, the White House attaches particular importance to strengthening energy ties with Ak Orda, and seeks to ensure the interests of US companies involved in the development of fuel and energy complex (FEC) 
of the Republic of Kazakhstan. In this regard, the Kazakh energy sector receives more than $65 \%$ of all US investments in the Kazakh economy (Sultanov, 2012).

The main document on deepening energy cooperation between Kazakhstan and the US is a declaration on energy partnership between the US and Kazakhstan. Kazakhstan's president, Nursultan Nazarbayev signed this document during his official visit to the US during December 20-23, 2001.

This declaration defined the cooperation regarding energy security, oil and gas, electricity, nuclear energy, and environmental security. For the realization of the declaration, the Special Commission for the partnership in the field of energy was created (later renamed to the joint Kazakh-American Commission on Energy Partnership), and led by the representatives of the relevant ministries.

Between 2001 and 2012, there were nine sessions of refueling monitoring system (RMS). Its activity was balanced between the four areas: nuclear security and energy; hydrocarbon resources; renewable energy and energy efficiency; and electric power.

The official opening of the representative office of the joint stock company (JSC) "NAC Kazatomprom" in the US was held May 16, 2013 in Washington. Its mission was to develop cooperation projects with American partners, to establish direct contacts with the end users of uranium in the US, and the promotion of projects for entering the sale of nuclear fuel cycle products of higher benefit, and others.

The strategic importance of Central Asia as a "high-risk region" and the meeting of interests of Russia, China, and Iran, which are three long-term rivals of Washington, also influenced the US in the development of relations with Kazakhstan. The power factor enhances American interest, since the US regards Kazakhstan as the largest exporter playing a significant role in the global energy market. Geostrategic and energy factors determine the importance of Kazakhstan's foreign policy with Washington, according to a former US Assistant to the President for National Security, Zbigniew Bzhezinski (2010), who said they "can play an important role in ensuring regional security".

In the spring of 1994, an active process of attracting private American companies in projects started under the framework of privatization. The oil company "Chevron" was a pathfinder in the Kazakh market, which has signed the largest exploration contract for the Tengiz field in western Kazakhstan in the post-Soviet space

The discovery of new oil fields in the North Caspian Sea played a positive role. The US Administration has the Caspian region at the forefront of its foreign policy, and actively promotes the interests of American companies to the Caspian countries.

The cooperation in trade and economic sphere is an important area of the Kazakh-American relations. The US ranks first in the total volume of direct investments in the economy of Kazakhstan. For 2012, the trade turnover between Kazakhstan and the US amounted to USD 2.56 billion, which is $6.8 \%$ less than in 2011 (USD 2.74 billion). The foreign trade balance is negative, amounting to USD 1.67 billion in 2012.

Kazakhstan exports to the US for 2012 equaled USD 0.44 billion, which is $57.1 \%$ less than that of 2011 (USD 1.03 billion). The main products exported to the US are crude oil and crude oil products, chemical elements and radioactive isotopes of silver, ferrous alloys, and titanium, and similar products.

Imports from the US to Kazakhstan in 2012 amounted to USD 2.12 billion, which is $23.4 \%$ more than in the same period of 2011 (USD 1.71 billion). The main imported goods are parts for railway locomotives and rolling stock, meat and edible offal of poultry, air and vacuum pumps, internal combustion engines, and instruments and appliances used in medical, surgical, dental and veterinary medicine. 
Currently, Kazakhstan has 325 Kazakhstan-American joint ventures and about 100 representatives of different companies registered. In addition, there are more than 50 US non-government organizations (NGOs) in Kazakhstan under Kazakhstan's NGO agreement.

Of particular importance is the cooperation with the US business in the oil and gas sector. The productive chain, from research to production, refining, and transportation of hydrocarbons, and refined products, engages US companies, with the support of the political leadership of the US.

Currently in Kazakhstan, almost all large American oil companies are involved in the implementation of nearly all the major oil and gas projects in Kazakhstan. Serious plans of US companies are confirmed by their activities outside of oil production, which include projects of complex processing of raw materials, the creation of local infrastructure, addressing environmental and social issues.

American leadership is paying special attention to establishing the pipeline infrastructure from the Caspian region as a part of a global strategy for ensuring the energy security of the US. In this area, the Clinton administration pursued a policy of multi-variant pipeline with the aim of ensuring an uninterrupted supply of Caspian oil to the world market, based on the substitutability of export routes of transportation.

At a meeting with President Nazarbayev in Washington in November 1997, Strobe Talbott, the Deputy Secretary of State in the US, stressed the importance of addressing complex transportation problems for the future of Kazakhstan by stating that the US will support all developed and new export routes of hydrocarbons, except Iran, in all directions along the axis of the East-West, North-South (Almadiyev, 2015, p. 362).

The continuity of energy policy remained after the change of administration. Potential exports from the Caspian region could reach 1.8 million barrels of oil per day by 2005, as the US will work closely with private companies and countries in the region for the development of commercially viable export routes, as the oil pipeline "Baku-Tbilisi-Ceyhan" and "CPC" US-backed pipeline routes "East-West" will add a new oil and transport capacity that will continue and increase in the production and export.

Stephen Sestanovicha, the U.S. State Department's ambassador-at-large for the former Soviet Union, visited Kazakhstan in July 2000, in relation to the US policy toward the nuclear installation safety (NIS). This was followed by the visit of Bill Richardson, the US Energy Secretary, in August to further strengthen cooperation in the field of energy. The prospect of having an alternative, sustainable source of oil from the Caspian region had increased lobbying for the export pipeline project "Baku-TbilisiCeyhan oil pipeline".

The position of Kazakhstan in relation to the pipeline remained generally positive, especially since this project could not occur without Kazakh oil. Not having any political reservations on the draft, Kazakhstan proceeded from the viewpoint of commercial feasibility of the pipeline. Astana considered it a priority project of the Caspian Pipeline Consortium, not excluding their participation in the project "Baku-Tbilisi-Ceyhan oil pipeline."

The cooperation with US companies, for the development of mining and processing complexes, is also important to the economy of Kazakhstan. The diversity of raw minerals in Kazakhstan, the demand for which, on the world market, is steadily increasing, is a good prerequisite for further bilateral cooperation.

A positive aspect of cooperation was the US's recognition of the leadership of Kazakhstan (reformative and economical) in Central Asia, and to a certain extent, in the CIS. Washington concluded that it was necessary for Astana to take a role as leader in the region, which would contribute to the development of energy sector infrastructure and the creation of additional transit routes for energy (Institute for Central Asian and Caucasian Studies, 2007). Kazakhstan was the first among the CIS republics that the 
US has officially recognized as having a market economy. To date, the volume of US investments in the republic is about USD 12 billion. The American strategy with Kazakhstan had a distinct geopolitical context and a strategic military subtext. Nevertheless, the President of the Republic of Kazakhstan, Nursultan Nazarbaev has gained a balanced relationship with the US, and this has not affected the relations between Kazakhstan and other countries, or the safety of the international position of the country (Laumulin, 2009).

In July 2013, the Minister of Foreign Affairs, Erlan Idrisov, visited the US for negotiations with the new US Secretary of Energy, Ernest Jeffrey Moniz. The main topic was the preparation for the jubilee of the 10th meeting of the joint Kazakh-American Commission on energy. Under the framework of the partnerships involving "Green Bridge" and "EXPO-2017", the Minister proposed to include the issues of cooperation in the Commission's agenda.

In addition to cooperation in the field of renewable energy and energy efficiency, America was interested in cooperating in respect to civil nuclear energy. Thus, Ernest Jeffrey Moniz advised of the development of technology for modular small reactors in the US, with two or three such reactors planned for the US by 2022. However, Americans are still concerned about the separation of supervisory functions that ensure nuclear safety and functions in the nuclear industry, according to the Committee for Atomic Energy of the Ministry of Innovation and New Technologies (MINT) RoK.

In the field of non-proliferation, the Americans promised to provide all possible support in negotiating the position of the International Atomic Energy Agency (IAEA) project, Host Country Agreement, on Kazakh territory, gaining a place in the International Bank of low-enriched uranium. As known, a number of legal, technical, and financial issues contradict the legislation of Kazakhstan and violates the country's sovereignty.

Astana confirmed its readiness to host the Nuclear Security Summit in 2016, although Ernest Jeffrey Moniz informed of the alleged intention of the President Obama to hold the Summit in the US.

Most likely, the US Energy Department, who said, "Kazakhstan is regarded as a key US partner in the region", will continue to focus on further development of the energy dialogue between the two countries.

\section{Conclusion}

In general, the accumulated experience of joint solutions to many complex issues in the field of nonproliferation of nuclear weapons development at an appropriate level of political dialogue, and increasing mutual trade and investment, have created a solid foundation of mutual trust. This allows Kazakhstan and the US to find and solve problems without serious damage to relations of strategic partnerships and energy cooperation.

The analysis also shows that fundamental principles form the basis of the Kazakhstan-American relationship. These include the sovereign inviolability of the political and economic justifications of decisions, phasing, pragmatism, and mutual benefits. Such approaches are given in the "Foreign Policy Concept of the Republic of Kazakhstan", developed in accordance with the settings outlined in the Address of the President of the Republic of Kazakhstan, Leader of the Nation, to the Nation of Kazakhstan for "Strategy Kazakhstan-2050: a new policy of the established state".

\section{References}

Almadiyev, B. B. (2015). Kazakhstan and America: the Frontiers of Energy Diplomacy. European Researcher, 94(5), 356364. doi: 10.13187/er.2015.94.356

Bzhezinsky, Z. B. A. (2010). Great chess board. Moscow: International relations. 
Idrissov, E. A. (2014a, October 16). Diplomacy of Kazakhstan: for cooperation with affirmative results for everyone, an interview of the Minister for Foreign Affairs of the Republic of Kazakhstan. Retrieved from http://mfa.gov.kz/index.php/ru/blog-ministra-1/intervyu-i-vystupleniya-ministra/2101-diplomatiya-kazakhstana-zasotrudnichestvo-s-polozhitelnym-rezultatom-dlya-vsekh.

Idrissov E. A. (2014b, October 9) Last year, the Ministry of Foreign Affairs launched a large-scale of work on the expansion of geography of partners of Kazakhstan in the new regions of the world for us. An interview of the Minister for Foreign Affairs of the Republic of Kazakhstan. . Retrieved from: http://www.zakon.kz/4659067-peregovory-i-soglasovanie.html.

Institute for Central Asian and Caucasian Studies. (2007). Central Asian Analytical yearbook, 2006. Lulea: CA \& CC Press.

Laumulin, M. T. (2009). Central Asia in foreign politics and world geopolitics. Volume V: Central Asia in the XXI century. Almaty: KISS under the President of the Republic of Kazakhstan.

Ministry of Foreign Affairs of the Republic of Kazakhstan. (2014, January 21). Foreign Policy Concept for 2014-2020 of the Republic of Kazakhstan approved by the Decree of the President of the Republic of Kazakhstan Retrieved from http://mfa.gov.kz/index.php/ru/vneshnyaya-politika/kontseptsiya-vneshnoj-politiki-rk-na-2014-2020-gg.

Ministry for Foreign Affairs of the Republic of Kazakhstan. (n.d. a). Materials of Priorities of Kazakhstan diplomacy - to achieve a peace in Ukraine, to provide a sustainable development for our country. Retrieved from http://www.mfa.kz/index.php/ru/component/content/article/73-zapisi-ministra/3080-prioritety-kazakhstanskoj-diplomatiidostizhenie-mira-v-ukraine-obespechenie-ustojchivogo-razvitiya-nashej-strany.

Ministry for Foreign Affairs of the Republic of Kazakhstan. (n.d. b) Cooperation of Kazakhstan with the US of America. Retrieved from: http://www.mfa.kz/index.php/ru/vneshnyaya-politika/sotrudnichestvo-kazakhstana/sotrudnichestvo-sostranami-ameriki/12-material-orys/382-sotrudnichestvo-respubliki-kazakhs.

Ministry for Foreign Affairs of the Republic of Kazakhstan. (n.d. c) Cooperation of Kazakhstan with Canada. Retrieved from http://www.mfa.kz/index.php/ru/vneshnyaya-politika/sotrudnichestvo-kazakhstana/sotrudnichestvo-so-stranami-ameriki/12material-orys/400-sotrudnichestvo-respubliki-kazakhstan-s-kanadoj.

Ministry for Foreign Affairs of the Republic of Kazakhstan (n.d. d) Cooperation of Kazakhstan with the United Mexican States. Retrieved from: http://www.mfa.kz/index.php/ru/vneshnyaya-politika/sotrudnichestvo-kazakhstana/sotrudnichestvo-sostranami-ameriki/12-material-orys/1731-sotrudnichestvo-kazakhstan-mexico.

Ministry for Foreign Affairs of the Republic of Kazakhstan (n.d. e) Cooperation of the Republic of Kazakhstan with the Bolivarian Republic of Venezuela. Retrieved from: http://www.mfa.kz/index.php/ru/vneshnyaya-politika/sotrudnichestvokazakhstana/sotrudnichestvo-so-stranami-ameriki/12-material-orys/1736-sotrudnichestvo-kazakhstan-venezuela.

Ministry for Foreign Affairs of the Republic of Kazakhstan (n.d. f) Cooperation of the Republic of Kazakhstan with the Federative Republic of Brazil. Retrieved from: http://www.mfa.kz/index.php/ru/vneshnyaya-politika/sotrudnichestvokazakhstana/sotrudnichestvo-so-stranami-ameriki/12-material-orys/387-sotrudnichestvo-respubliki-kazakhstan-sfederativnoj-respublikoj-braziliya.

Ministry for Foreign Affairs of the Republic of Kazakhstan (n.d. g) Cooperation of the Republic of Kazakhstan with the Argentine Republic. Retrieved from: http://www.mfa.kz/index.php/ru/vneshnyaya-politika/sotrudnichestvokazakhstana/sotrudnichestvo-so-stranami-ameriki/12-material-orys/383-sotrudnichestvo-respubliki-kazakhstan-sargentinskoj-respubl.

Nazarbayev, N. (2012, December 14). The Strategy Kazakhstan-2050: new policy of the established state. Address to the people of Kazakhstan by the President, the Leader of the Nation of the Republic of Kazakhstan. Retrieved from: http://www.akorda.kz/ru/page/page_poslanie-prezidenta-respubliki-kazakhstan-lidera-natsii-nursultana-nazarbaeva-narodukazakhstana.

Sultanov, B. K. (Ed.). (2012). The problems of global energy: the experience for Kazakhstan. Almaty: Kazakhstan Institute for Strategic Studies.

The US Energy Independence and Security Act (2007). Retrieved from: http://www.epa.gov/lawsregs/laws 